\title{
Seeking the best system to protect human rights: should we follow the African cat or the Inter-American lion?
}

En busca del mejor sistema para proteger los Derechos Humanos:

¿deberíamos seguir al gato africano o al león Interamericano?

Autor: Francesco Schmidt

DOI: https://doi.org/10.25058/1794600X.1784 


\title{
SEEKING THE BEST SYSTEM TO PROTECT HUMAN RIGHTS: SHOULD WE FOLLOW THE AFRICAN CAT OR THE INTER-AMERICAN LION?*
}

\author{
En busca del mejor sistema para proteger los Derechos \\ Humanos: ¿deberíamos seguir al gato africano o \\ al león Interamericano?
Em busca do melhor sistema de proteção dos direitos humanos: devemos seguir o gato africano ou o leão interamericano?

Dott. Francesco Schmidt ${ }^{a}$ francesco.schmidt@virgilio.it

Fecha de recepción: 12 de mayo de 2020 Fecha de revisión: 15 de mayo de 2020 Fecha de aceptación: 01 de junio de 2020

\section{SUMMARY}

DOI: https://doi.org/10.25058/1794600X.1784

Para citar este artículo:

Schmidt, F. (2020). Seeking the best system to protect human rights: should we follow the African cat or the Inter-American lion. Revista Misión Jurídica, 13(19) 28-38.

This article represents an attempt to compare the leading positive assets and the major fragilities of the Inter-American and the African human rights systems, in the light of the activity of the Commission and the Court in both systems. The analysis - focused on the main human rights instruments for both regions - is articulated in two sections, in their turn structured in multiple paragraphs. The first section explores the legal mandate of the bodies concerned. The second section examines the functioning in practice of such bodies, in the form of a review of how they use their legal mandate and what impact is concretely accomplished. Moreover, the article will discuss the pivotal influence of historical, social and other contextual factors, fundamental cornerstones of any consequential legal consideration on human rights systems.

\section{KEY WORDS}

Human Rights; Inter-American system; African system; IACHR; ACmHPR; IACtHR; ACtHPR.

\footnotetext{
* Reflection article that shows the result of a personal investigation developed within the context of the Advanced LL.M. Programme on European and International Human Rights Law offered by Leiden University.

a. Dott. Francesco Schmidt is an Advanced LL.M. candidate at Leiden University, where he serves as contributor to the Leiden Law Blog. He graduated in Law cum Laude and Honours at the University of Torino. He is alumnus of the Center for Transnational Legal Studies and the King's College London, as well as of Bergen University. He served as judge in the context of the Philip C. Jessup Moot Court Competition 2020, after having participated as a mooter in 2019.
} 


\section{RESUMEN}

Este artículo es un intento por comparar los recursos positivos más destacados, así como las debilidades más grandes de los Sistemas de Derechos Humanos Interamericano y Africano a la luz de las actividades de la Comisión y la Corte en ambos sistemas. El análisis, enfocado en los principales instrumentos de Derechos Humanos para ambas regiones, está articulado en dos secciones, a su vez estructuradas en varios párrafos. La primera sección explora el mandato legal de los respectivos organismos. La segunda explora el funcionamiento en la práctica de dichos organismos, bajo la forma de una revisión de cómo usan su mandato jurídico y cuál es concretamente el impacto que alcanza. Además, en este artículo se discutirá el papel clave de la influencia de los factores históricos, sociales y contextuales, pilares fundamentales de cualquier consideración legal que pueda hacerse al reflexionar sobre los sistemas de Derechos Humanos.

\section{PALABRAS CLAVES}

Derechos Humanos; Sistema Interamericano; Sistema Africano, Comisión Interamericana de Derechos Humanos (CIDH), Comisión Africana de Derechos Humanos y de los Pueblos (CADHP), Corte Interamericana de Derechos Humanos (Corte IDH), Corte Africana de Derechos Humanos y de los Pueblos (CorteAFDH).

\section{RESUMO}

Este artigo representa uma tentativa de comparar os principais ativos positivos e as grandes fragilidades dos sistemas interamericano e africano de direitos humanos, à luz da atividade da Comissão e da Corte em ambos os sistemas. A análise, centrada nos principais instrumentos de direitos humanos para as duas regiões, está dividida em duas seções, por sua vez estruturadas em múltiplos parágrafos. A primeira seção explora o mandato legal das agências em questão. A segunda seção examina como esses órgãos funcionam na prática, na forma de uma revisão de como eles usam seu mandato legal e que impacto é alcançado concretamente. Além disso, o artigo discutirá a influência fundamental de fatores históricos, sociais e outros contextuais, pedras angulares fundamentais de quaisquer considerações jurídicas consequentes nos sistemas de direitos humanos.

\section{PALAVRAS-CHAVE}

Direitos humanos, Sistema Interamericano, Sistema Africano, Comissão Interamericana de Direitos Humanos (CIDH), Comissão Africana dos Direitos Humanos e dos Povos (CADHP), Corte Interamericana de Direitos Humanos (Corte Interamericana); Tribunal Africano dos Direitos Humanos e dos Povos (TribunalAFDH).

\section{METHODOLOGY}

The research methods developed in the present paper have led to provide a comparison from both a theoretical and practical perspective - of the approaches to human rights protection between two regional human rights systems: the African and the Inter-American ones. The research activity has developed through several well-defined steps. As a first step, a research was developed in the library of Leiden University, to reflect on format and aims of the Article, as well as to brainstorm - in a lucid and balanced way - the broad range of topics connected to the imminent comparison.)

After this preliminary passage, the real research activity started, utilizing many different sources. A series of classical - and unbeatable - compendiums of legal knowledge have been consulted, to obtain an overall understanding of the essential elements in a short and readable fashion: inter alia, 'International Human Rights Law and Practice' (from I. Bantekas and L. Oette), 'International Law' (from M. N. Shaw), 'Brownlie's Principles of International Law' (from J. Crawford), 'International Law' (from M. D. Evans). But the research did not rely only on the authoritative guidance of these historical authors.

In fact, as a second step, a comprehensive online research has been developed, by means of numerous useful databases and websites. In this respect, a rich and indispensable source of knowledge and research has been the online catalogue of the Leiden University library system, allowing the author to find - in a very accessible way - useful and engaging academic materials. Another fundamental set of sources, used by the author to develop more detailed references, have been the most known online legal databases: inter alia, Westlaw, Hein Online, JSTOR have been resulted particularly comprehensive in their coverage. 
As a third step, the author combined the obtained materials with a careful use of the sites of the main concerned Courts and bodies, therefore ensuring both a better understanding and a critical analysis of the right to housing in the two relevant systems: the African Commission on Human and Peoples' Rights (https://www.achprorg/), the African Court on Human and Peoples' Rights (http://www.africancourt.org/en/), the Inter-American Commission on Human Rights (https://www.oas.org/en/iachr/), the Inter-American Court of Human Rights (http:// www.corteidh.or.cr/index-en.cfm).

Finally, it is worth mentioning that the final result represents an attempt to coherently assist the reader through a comprehensive path, encompassing both the overall conception of human rights in both systems and a more focused engagement on the current debate of their functioning.

\section{1) THE ROOT OF THE QUESTION: DIFFERENT LEGAL MANDATES}

Before addressing a substantive comparison in detail, it appears necessary to reflect on the reason underlying the coexistence - in both the considered systems - of two different bodies: a Commission and a Court. Such 'dual' nature is the necessary consequence of a common structural weakness: namely, the severe lack of universality in the acceptance, from the relevant States, of the contentious jurisdiction of $\operatorname{IACtHR}^{1}$ and ACtHPR $^{2}$. The absence of widespread consent on these more 'legal' bodies, makes it essential the

1. Bantekas and Oette, International Human Rights Law and Practice, Cambridge University Press, Second Edition, 2016, p 274; Heyns, Padilla, Zwaak, 'A schematic comparison of Regional Human Rights Systems: an update', 2006, 3 International Journal on Human Rights 4, p 165; Goldman, 'History and Action: The Inter-American Human Rights System and the Role of the InterAmerican Commission on Human Rights,' 2009, 31 Human Rights Quarterly 4, p 866; Canton, 'To Strengthen Human Rights, Change the OAS (Not the Commission)', 2013, 20 Human Rights Brief 2, $p$ 3; Pinto, 'The Role of the Inter-American Commission and Court of Human Rights in the Protection of Human Rights: Achievements and Contemporary Challenges', 2013, 20 Human Rights Brief 2, p 1-2; Völkerrechtsblog, The Inter-American System has always been in crisis, and we always found a way out": an interview with Eduardo Ferrer Mac-Gregor Poisot, by L. Sanchez and R. Kunz, 17 October 2016.

2. Bantekas and Oette, International Human Rights Law and Practice, Cambridge University Press, Second Edition, 2016, p 283; Huneeus, Rask Madsen, 'Between universalism and regional law and politics: a comparative history of the American, European, and African human rights systems', 2018, 16 Internationa Journal of Constitutional Law 1, p 158; Heyns, Padilla, Zwaak A schematic comparison of Regional Human Rights Systems: an update', 2006, 3 International Journal on Human Rights 4, p 165. concurrent presence of the two more 'political' bodies: respectively, IACHR ${ }^{3}$ and $\mathrm{ACmHPR}^{4}$.

\section{1) Comparing the political bodies: the IACHR and the ACMHPR}

The main common strength is constituted by the broad nature of their legal mandate, which renders both Commissions effective and proactive organs in two directions: the promotion and the protection of human rights. Their role is crucially strengthened by such double function: it allows both the $\mathrm{IACHR}^{5}$ and the ACmHPR ${ }^{6}$ to not limit themselves at developing awareness on human rights issues, but to broaden a really substantial and judicial function through the study of specific situations with fact-finding missions and country-visits, direct investigations of human rights' violations and consequent issuances of recommendations to the involved State. Nevertheless, their mandates cannot be described as fully overlapping. On the promotional aspect, the powers of the ACmHPR seem more vigorous in so far as the States are required to submit a report every two years to its consideration; conversely, the absence of such reportingsystem in the Inter-American Commission can

3. Huneeus, Rask Madsen, 'Between universalism and regional law and politics: a comparative history of the American European, and African human rights systems', 2018, 16 International Journal of Constitutional Law 1, p 146.

4. Viljoen, 'From a cat into a lion? An overview of the progress and challenges of the African human right system at the African Commission's 25-year mark', 2013, 17 Law, Democracy and Development, $p 300$.

5. Bantekas and Oette, International Human Rights Law and Practice, Cambridge University Press, Second Edition, 2016, p 264-265; Huneeus, Rask Madsen, 'Between universalism and regional law and politics: a comparative history of the American, European, and African human rights systems', 2018, 16 International Journal of Constitutional Law 1, p 144; Goldman, 'History and Action: The Inter-American Human Rights System and the Role of the Inter-American Commission on Human Rights, 2009, 31 Human Rights Quarterly 4, p 866, 868; Canton, 'To Strengthen Human Rights, Change the OAS (Not the Commission)', 2013, 20 Human Rights Brief 2, p 1; Pinto, 'The Role of the Inter-American Commission and Court of Human Rights in the Protection of Human Rights: Achievements and Contemporary Challenges,' 2013, 20 Human Rights Brief 2, $p$ 1; Inter-American Commission on Human Rights (IACHR), Severe Financial Crisis of the IACHR Leads to Suspension of Hearings and Imminent Layoff of Nearly Half its Staff, Press Release, 23 May 2016; Engstrom, 'Reconceptualising the Impact of the InterAmerican Human Rights System', 2017, 2 Revista Direito and Praxis 8, p 1257.

6. Bantekas and Oette, International Human Rights Law and Practice, Cambridge University Press, Second Edition, 2016, p 277; Viljoen, 'From a cat into a lion? An overview of the progress and challenges of the African human right system at the African Commission's 25-year mark', 2013, 17 Law, Democracy and Development, $p 301$. 
righteously be considered a weakness. $^{7}$ In contrast, the IACHR can boast the compresence of thematic and country-specific rapporteurs, while the African system can rely on just the thematic ones. ${ }^{8}$ However, the core weakness of the ACmHPR certainly consists in its structural lack of independence from the States, ${ }^{9}$ which can exercise a huge influence on its mandate by preventing the publication of its judicial decisions. ${ }^{10}$ Yet, it must be recognised to the ACmHPR a broader admissibility of individual complaints $^{11}$ through the actio popularis mechanism, while the individual-petition system of the IACHR - although well-developed $-{ }^{12}$ lacks this useful instrument.

\section{2) The role of Courts: differences in legal mandate between IACtHR and ACtHPR}

The legal mandate of the two Courts is broad, giving them a far-reaching legal basis to effectively defend human rights. Both the IACtHR ${ }^{13}$ and the $\mathrm{ACtHPR}^{14}$ have a strong contentious jurisdiction,

7. Heyns, Padilla, Zwaak, 'A schematic comparison of Regional Human Rights Systems: an update', 2006, 3 International Journal on Human Rights 4, p 168.

8. Heyns, Padilla, Zwaak, 'A schematic comparison of Regional Human Rights Systems: an update', 2006, 3 International Journal on Human Rights 4, p 169.

9. University of Pretoria, Centre for Human Rights (Faculty of Law), Centre for Human Rights Calls for Autonomy and Independence of the African Commission to Be Reaffirmed; and for Action on Cameroon and Eritrea, 28 April 2018, $p 1$.

10. Heyns, Padilla, Zwaak, 'A schematic comparison of Regional Human Rights Systems: an update', 2006, 3 International Journal on Human Rights 4, $p 168$.

11. Huneeus, Rask Madsen, 'Between universalism and regional law and politics: a comparative history of the American European, and African human rights systems,' 2018, 16 International Journal of Constitutional Law 1, p 150.

12. Canton, 'To Strengthen Human Rights, Change the OAS (Not the Commission)', 2013, 20 Human Rights Brief 2, p 2; Pinto, 'The Role of the Inter-American Commission and Court of Human Rights in the Protection of Human Rights: Achievements and Contemporary Challenges,' 2013, 20 Human Rights Brief 2, $p 1$.

13. Bantekas and Oette, International Human Rights Law and Practice, Cambridge University Press, Second Edition, 2016, $p$ 266-267; Goldman, 'History and Action: The Inter-American Human Rights System and the Role of the Inter-American Commission on Human Rights,' 2009, 31 Human Rights Quarterly 4, p 857, 884; Völkerrechtsblog, The Inter-American System has always been in crisis, and we always found a way out": an interview with Eduardo Ferrer Mac-Gregor Poisot, by L. Sanchez and R. Kunz, 17 October 2016; Antkowiak, 'Remedial Approaches to Human Rights Violations: The Inter-American Court of Human Rights and Beyond', 2008, 46 Columbia Journal of Transnational Law 2, p 353 (and following)

14. Bantekas and Oette, International Human Rights Law and Practice, Cambridge University Press, Second Edition, 2016, p 282-283. allowing them - not only to judge on whether a violation of human rights has been committed - but also to order remedies for the occurred violation: both can rely on a significantly broad mandate on reparations. Moreover, neither of them need a permission to publish their decisions: clear sign of independence from States. ${ }^{15}$ However the legal mandate of the IACtHR presents some structural weaknesses, if compared to the one of the ACtHPR. Primarily, in case of individual complaints, there is no possibility of direct access to the Court: only the States or the Commission can seize the IACtHR. ${ }^{16}$ Conversely, direct access to the ACtHPR is possible, on condition that the concerned State has made a special declaration allowing it. ${ }^{17}$ Nonetheless, an increasing attention for victims must still be recognised to the IACtHR: if the individual petition is referred to the Court, they can directly participate in the process. ${ }^{18}$ Secondly, the legal mandate of the Inter-American Court is fatally undermined by the absence of a mechanism - in the system - specifically devoted to the control over compliance with its judgements. ${ }^{19}$ Instead, such crucial tool is present

15. Heyns, Padilla, Zwaak, 'A schematic comparison of Regional Human Rights Systems: an update,' 2006, 3 International Journa on Human Rights 4, p 168.

16. Huneeus, Rask Madsen, 'Between universalism and regional law and politics: a comparative history of the American European, and African human rights systems', 2018, 16 International Journal of Constitutional Law 1, p 158; Engstrom, 'Reconceptualising the Impact of the Inter-American Human Rights System', 2017, 2 Revista Direito and Praxis 8, p 1262.

17. Huneeus, Rask Madsen, 'Between universalism and regional law and politics: a comparative history of the American, European, and African human rights systems, 2018, 16 International Journal of Constitutional Law 1, p 158; Viljoen, 'From a cat into a lion? An overview of the progress and challenges of the African human right system at the African Commission's 25-year mark', 2013, 17 Law, Democracy and Development, p 308; Gyan Nyarko, Oluborode Jegede, 'Recent developments: Human rights developments in the African Union during 2016',2017, 17 African Human Rights Law Journal, p 304, 308; Killander, Gyan Nyarko, 'Recent developments: Human rights developments in the African Union (January 2017-September 2018)', 2018, 18 African Human Rights Law Journal, $p$ 742, 757.

18. E.g. It is remarkable the direct role of victims and their representatives in Saramaka People $v$ Suriname, InterAmerican Court of Human Rights (IACtHR), Judgement (Merits, Reparations and Costs), Series C No. 172, 28 November 2007, e.g. paras 4, 16, 21. For more analysis on the theory: Bantekas and Oette, International Human Rights Law and Practice, Cambridge University Press, Second Edition, 2016, p 267; Lixinski, 'Treaty Interpretation by the Inter-American Court of Human Rights: Expansionism at the Service of the Unity of International Law', 2010, 21 The European Journal of International Law 3, p 601; Pinto, 'The Role of the Inter-American Commission and Court of Human Rights in the Protection of Human Rights: Achievements and Contemporary Challenges', 2013, 20 Human Rights Brief 2, p 3.

19. Goldman, 'History and Action: The Inter-American Human 
in the African system. ${ }^{20}$ A third strength of the ACtHPR - when compared to the IACtHR ${ }^{21}$ is the possibility for NGOs to request advisory opinions, albeit under specific conditions. ${ }^{22}$

\section{2) FUNCTIONING IN PRACTICE: WHO PRODUCES BETTER RESULTS?}

A meaningful analysis of the practical functioning and the concrete impact of human rights' bodies cannot avoid considering the influence of contextual and historical factors. The fact that the development of the Inter-American human rights system started just after the WWII ${ }^{23}$ - when human rights law was a 'blank page' can help explaining its inherent creative and innovative nature, characteristically materialised in the flowering of new interpretative methods. Conversely, the fact that the African system began to evolve some decades later ${ }^{24}$ - when the

Rights System and the Role of the Inter-American Commission on Human Rights', 2009, 31 Human Rights Quarterly 4, $p$ 884; Canton, 'To Strengthen Human Rights, Change the OAS (Not the Commission)', 2013, 20 Human Rights Brief 2, p 3, 7, 8; Engstrom, 'Reconceptualising the Impact of the Inter-American Human Rights System', 2017, 2 Revista Direito and Praxis 8, $p$ 1254. The fact that - as a result of such crucial absence - 'The Court [itself] shall monitor full compliance with this Judgment, in exercise of its attributes and in compliance with its obligations under the American Convention' is well described by Saramaka People v Suriname, Inter-American Court of Human Rights (IACtHR), Judgement (Merits, Reparations and Costs), Series C No. 172, 28 November 2007, $p$ 62, para 15.

20. On the enforcement role of Assembly and Executive Council of the African Union: Bantekas and Oette, International Human Rights Law and Practice, Cambridge University Press, Second Edition, 2016, p 282-283; Heyns, Padilla, Zwaak, 'A schematic comparison of Regional Human Rights Systems: an update', 2006, 3 International Journal on Human Rights 4, $p 168$.

21. Huneeus, Rask Madsen, 'Between universalism and regional law and politics: a comparative history of the American, European, and African human rights systems', 2018, 16 International Journal of Constitutional Law 1, p 146.

22. Killander, Gyan Nyarko, 'Recent developments: Human rights developments in the African Union (January 2017-September 2018)', 2018, 18 African Human Rights Law Journal, p 744, 746

23. Bantekas and Oette, International Human Rights Law and Practice, Cambridge University Press, Second Edition, 2016, p 262-263; Huneeus, Rask Madsen, 'Between universalism and regional law and politics: a comparative history of the American, European, and African human rights systems', 2018 16 International Journal of Constitutional Law 1, p 139-140 Goldman, 'History and Action: The Inter-American Human Rights System and the Role of the Inter-American Commission on Human Rights', 2009, 31 Human Rights Quarterly 4, $p$ 859-862.

24. Bantekas and Oette, International Human Rights Law and Practice, Cambridge University Press, Second Edition, 2016, p 274-275; Huneeus, Rask Madsen, 'Between universalism and regional law and politics: a comparative history of the American, European, and African human rights systems' 2018, 16 International Journal of Constitutional Law 1, p 149-150; Viljoen, 'From a cat into a lion? An overview of the progress and first human rights standards had already been established - is unquestionably significant on its distinctive openness to external sources. Both social environment and economic circumstances have a substantial impact on the diversification of the human rights bodies' activity. The widespread phenomena of discrimination and marginalization of indigenous communities in Latin America ${ }^{25}$ led the Inter-American system to develop a particular sensitivity on such issues, through the introduction of vital principles as the FPIC requirement and a broad caselaw on reparations. As for the African system, its valuable reactiveness on themes as the right to self-determination or the control over natural resources appears to be inextricably connected to the decolonization process and the gaining of States' independence. ${ }^{26}$ On the other hand, the overall context might also explain some weaknesses of the systems. The deep ideological controversies between the States' parties have rendered the Inter-American system increasingly politicised, to the point of creating a tangible risk of detrimental backlash after years of progressive expansionist approach in human rights' protection. ${ }^{27}$ In the African system, an excessive emphasis on the protection of the African cultural values can dramatically result in the legitimation of ongoing oppressions against LGBTQIA+ people, ${ }^{28}$ in respect of which the InterAmerican system has instead established itself as a model of protection. ${ }^{29}$

challenges of the African human right system at the African Commission's 25-year mark', 2013, 17 Law, Democracy and Development, $p$ 298-299.

25. Goldman 'History and Action: The Inter-American Human Rights System and the Role of the Inter-American Commission on Human Rights,' 2009, 31 Human Rights Quarterly 4, $p$ 875; Lixinski, 'Treaty Interpretation by the Inter-American Court of Human Rights: Expansionism at the Service of the Unity of International Law', 2010, 21 The European Journal of International Law 3, p 594.

26. Huneeus, Rask Madsen, 'Between universalism and regional law and politics: a comparative history of the American, European, and African human rights systems', 2018, 16 International Journal of Constitutional Law 1, p 142, 149.

27. Huneeus, Rask Madsen, 'Between universalism and regional law and politics: a comparative history of the American, European, and African human rights systems, 2018, 16 International Journal of Constitutional Law 1, p 1153-154 Engstrom, 'Reconceptualising the Impact of the Inter-American Human Rights System', 2017, 2 Revista Direito and Praxis 8, $p$ 1273-1274.

28. Gyan Nyarko, Oluborode Jegede, 'Recent developments: Human rights developments in the African Union during 2016, 2017, 17 African Human Rights Law Journal, $p 300$.

29. Contesse, 'The Inter-American Court of Human Rights' Advisory Opinion on Gender Identity and Same-Sex Marriage', 2018, 22 American Society of International Law - Insights 9. 


\section{1) The impact of the Commissions}

The IACHR's activity is manifestly more developed if compared to its African counterpart. It is enough to mention that it judges around one hundred individual communications per years: ${ }^{30}$ tenfold the number examined by ACmHPR. ${ }^{31}$ Again, the reason relies on the history of these systems: IACHR is active since $1960,{ }^{32}$ while ACmHPR has been established only in $1987 . .^{33}$ Consequently ACmHPR has spent the last decades in a slow evolution of its authority, ${ }^{34}$ whereas IACHR has reached earlier a critical role in the setting of human rights standards. ${ }^{35}$ Illustrations of such decisive role could be numerous: just to name a few, duty to punish those responsible for gross human rights violations, limits to military jurisdiction, and protection of women's rights as well as of freedom of expression. ${ }^{36}$ Nevertheless, it

30. Heyns, Padilla, Zwaak, 'A schematic comparison of Regional Human Rights Systems: an update', 2006, 3 International Journal on Human Rights 4, $p 166$.

31. It is clear that 'This number is not only strikingly lower than the number of cases in the other regional systems, but also a drop in the ocean considering the pool of potential cases. It must be abundantly clear that 17 cases per year, in a vast continent comprising $53 A U$ member states, is unacceptably low', as reported in Viljoen, 'From a cat into a lion? An overview of the progress and challenges of the African human right system at the African Commission's 25-year mark', 2013, 17 Law, Democracy and Development, $p$ 307; Heyns, Padilla, Zwaak, 'A schematic comparison of Regional Human Rights Systems: an update', 2006, 3 International Journal on Human Rights 4, $p 166$.

32. Huneeus, Rask Madsen, 'Between universalism and regional law and politics: a comparative history of the American, European and African human rights systems', 2018, 16 International Journal of Constitutional Law 1, p 140; Heyns, Padilla, Zwaak, 'A schematic comparison of Regional Human Rights Systems: an update', 2006, 3 International Journal on Human Rights 4, $p$ 166; Goldman, 'History and Action: The Inter-American Human Rights System and the Role of the Inter-American Commission on Human Rights', 2009, 31 Human Rights Quarterly 4, $p 862$.

33. Huneeus, Rask Madsen, 'Between universalism and regional law and politics: a comparative history of the American, European, and African human rights systems', 2018, 16 International Journal of Constitutional Law 1, p 149; Heyns, Padilla, Zwaak, 'A schematic comparison of Regional Human Rights Systems: an update', 2006, 3 International Journal on Human Rights 4, $p$ 166; Viljoen, 'From a cat into a lion? An overview of the progress and challenges of the African human right system at the African Commission's 25-year mark', 2013, 17 Law, Democracy and Development, $p 299$.

34. Huneeus, Rask Madsen, 'Between universalism and regional law and politics: a comparative history of the American, European, and African human rights systems', 2018, 16 International Journal of Constitutional Law 1, p 157.

35. Engstrom, 'Reconceptualising the Impact of the InterAmerican Human Rights System,' 2017, 2 Revista Direito and Praxis 8, $p 1257$.

36. Canton, 'To Strengthen Human Rights, Change the OAS (Not the Commission)', 2013, 20 Human Rights Brief 2, $p$ 1-2; Pinto, would be mistaken to imply a too harsh judgement against the African Commission. Indeed, its decisions are - not only increasingly extensive and better argued - but also progressively manifesting expansionist interpretations. A model of its holistic approach to human rights can be found in the landmark decision concerning the Ogoni communities. ${ }^{37}$ Here, ACmHPR recognized protection to new rights not expressly mentioned in the African Charter - namely the right to housing $^{38}$ and the right to food - by means of connecting them to rights explicitly guaranteed by the Charter ${ }^{39}$ Also, this decision demonstrates the ACmHPR's dynamic approach: it historically established the justiciability of socio-economic rights, furthermore addressing the right to health - not only in its individual dimension - but also as a collective human rights connected to the protection of the environment. ${ }^{40}$ An innovative connection, which soon thereafter has been followed by IACHR. ${ }^{41}$ Moreover, here ACmHPR manifestly integrates external sources, relying on the possibility given by Articles 60 and 61 of the Charter ${ }^{42}$ The Commission uses outer standards to support its own findings, even surpassing the breakthroughs implemented by IACHR in this

'The Role of the Inter-American Commission and Court of Human Rights in the Protection of Human Rights: Achievements and Contemporary Challenges', 2013, 20 Human Rights Brief 2, $p 2$.

37. African Commission on Human and Peoples' Rights, Social and Economic Rights Action Center (SERAC) and Center for Economic and Social Rights (CESR) v Nigeria, Communication No. 155/96, 27 May 2002.

38. African Commission on Human and Peoples' Rights, Social and Economic Rights Action Center (SERAC) and Center for Economic and Social Rights (CESR) v Nigeria, Communication No. 155/96, 27 May 2002, paras [59-63] (on the right to housing), paras [64-66] (on the right to food).

39. Viljoen, 'From a cat into a lion? An overview of the progress and challenges of the African human right system at the African Commission's 25-year mark', 2013, 17 Law, Democracy and Development, $p$ 303, 311.

40. African Commission on Human and Peoples' Rights, Social and Economic Rights Action Center (SERAC) and Center for Economic and Social Rights (CESR) v Nigeria, Communication No. 155/96, 27 May 2002, paras [50-53].

41. Lixinski, 'Treaty Interpretation by the Inter-American Court of Human Rights: Expansionism at the Service of the Unity of International Law', 2010, 21 The European Journal of International Law 3, p 594-595.

42. African Commission on Human and Peoples' Rights, Social and Economic Rights Action Center (SERAC) and Center for Economic and Social Rights (CESR) v Nigeria, Communication No. 155/96, 27 May 2002, para [57] (reference to the InterAmerican Court and to the ECtHR), para [63] (reference to General Comment No. 4 (1991) of the Committee on Economic, Social and Cultural Rights on the right to adequate housing). 
respect. ${ }^{43}$ A courageous attitude which - however - cannot make us forget the incumbent threat on the ACmHPR's action and potential impact: the increasing political pressures against its independence. ${ }^{44} \mathrm{~A}$ menace endangering IACHR as well, if we scrutinize in this light the severe financial crisis affecting its activity. ${ }^{45}$ Current challenges that - especially if examined taking into account the common weakness consisting in the widespread lack of a rule of law culture in both systems $-{ }^{46}$ make even more fundamental the role of the two Commissions as instruments of 'creative political human rights diplomacy',47 and not instead strictly legal bodies such as the two Courts. ${ }^{48}$

43. Lixinski, 'Treaty Interpretation by the Inter-American Court of Human Rights: Expansionism at the Service of the Unity of International Law', 2010, 21 The European Journal of International Law 3, $p 591$.

44. University of Pretoria, Centre for Human Rights (Faculty of Law), Centre for Human Rights Calls for Autonomy and Independence of the African Commission to Be Reaffirmed; and for Action on Cameroon and Eritrea, 28 April 2018. I would refer - as illustrations of the existing threat - to the case of the observer status of the NGO Coalition of African Lesbians (whose observer status to the African Commission has been withdrawn as a consequence of the ongoing political pressures) and to the recent decision of the Executive Council of African Union dated July 2018 (concerning the adjustment of the mandate and the status of the African Commission, that should be regularized as an organ of the African Union).

45. Goldman, 'History and Action: The Inter-American Human Rights System and the Role of the Inter-American Commission on Human Rights', 2009, 31 Human Rights Quarterly 4, p 883; Inter-American Commission on Human Rights (IACHR), Severe Financial Crisis of the IACHR Leads to Suspension of Hearings and Imminent Layoff of Nearly Half its Staff, Press Release, 23 May 2016.

46. Engstrom, 'Reconceptualising the Impact of the InterAmerican Human Rights System,' 2017, 2 Revista Direito and Praxis $8, p$ 1252, 1254.

47. Huneeus, Rask Madsen, 'Between universalism and regional law and politics: a comparative history of the American, European, and African human rights systems,' 2018, 16 International Journal of Constitutional Law 1, p 142. Crucial - in this respect - is the role of the African Commission as a forum for NGOs: in its sessions there is a strong involvement of hundreds of NGOs, that use its sessions to come together and discuss strategies. The relevance of such aspect has reached such a degree that it would not be hazardous to define the African Commission as a 'NGOs forum?. On this matter, see more on: Huneeus, Rask Madsen, 'Between universalism and regional law and politics: a comparative history of the American, European and African human rights systems', 2018, 16 International Journal of Constitutional Law 1, p 157.

48. Antkowiak, 'Remedial Approaches to Human Rights Violations: The Inter-American Court of

Human Rights and Beyond, 2008, 46 Columbia Journal of Transnational Law 2, p 358; nevertheless, we should also consider and balance the risk laying in prioritising excessively the promotional aspect over the substantive protection, in the activities of the Commissions - as explained in Viljoen, 'From a cat into a lion? An overview of the progress and challenges of the African human right system at the African Commission's 25-year

\section{2) The impact of the Courts}

Essential issues of confrontation between the two Courts are their interpretative principles and the use of their legal mandate on remedies and reparations. A broad range of progressive interpretations centered on judicial dialogue has played a key role in the IACtHR's activity: for decades, the Inter-American Court has pioneered dynamic doctrines such as the 'pro homine'49 and the 'effet utile'.50 Nowadays, numerous examples testify the ongoing expansionist approach of the Inter-American Court: just to name a few, its recent judgement on Lagos del Campo v Peru, its 2017 advisory opinion on environmental issues and its 2018 advisory opinion on LGBTQIA+ issues. $^{51}$ A fortiori its decision on Saramaka $v$ Suriname has significantly broadened the notion of right to life ${ }^{52}$, expanded indigenous peoples' rights $^{53}$ and confirmed the principle of reliance on all the IHRL corpus iuris. ${ }^{54}$ It would be wrong to deny

mark, 2013, 17 Law, Democracy and Development, $p$ 313-314.

49. Bantekas and Oette, International Human Rights Law and Practice, Cambridge University Press, Second Edition, 2016, p 142; Lixinski, 'Treaty Interpretation by the Inter-American Court of Human Rights: Expansionism at the Service of the Unity of International Law',2010, 21 The European Journal of International Law 3, p 588-589, 601, 603-604; Burgorgue-Larsen, 'Decompartmentalization: the Key Technique for Interpreting Regional Human Rights Treaties', 2018, 16 International Journal of Constitutional Law 1, p 196-197, 207.

50. Saramaka People v Suriname, Inter-American Court of Human Rights (IACtHR), Judgement (Merits, Reparations and Costs), Series C No. 172, 28 November 2007, para [20]; Lixinski, 'Treaty Interpretation by the Inter-American Court of Human Rights: Expansionism at the Service of the Unity of International Law', 2010, 21 The European Journal of International Law 3, $p$ 589 .

51. Contesse, 'The Inter-American Court of Human Rights' Advisory Opinion on Gender Identity and Same-Sex Marriage, 2018, 22 American Society of International Law - Insights 9.

52. The Inter-American Court has interestingly connected the right to life and the cultural identity of the indigenous community of Saramaka, as shown by Saramaka People v Suriname, InterAmerican Court of Human Rights (IACtHR), Judgement (Merits, Reparations and Costs), Series C No. 172, 28 November 2007, para [82]

53. The Court broadens it to the extent of requiring the free, prior and informed consent of the community prior to the access to their natural resources, as shown by Saramaka People $v$ Suriname, Inter-American Court of Human Rights (IACtHR) Judgement (Merits, Reparations and Costs), Series C No. 172, 28 November 2007, para [134].

54. By way of illustration: Saramaka People v Suriname, InterAmerican Court of Human Rights (IACtHR), Judgement (Merits, Reparations and Costs), Series C No. 172, 28 November 2007, paras [51], [72], [98], [131]; Brunner, 'The Rise of Peoples' Rights in the Americas: The Saramaka People Decision of the InterAmerican Court of Human Rights', 2008, 7 Chinese Journal of 
that - at least till today-ACtHPR has proved itself to be more cautious in this respect. Even in its recent Ogiek decision, the African Court has showed a more restrictive interpretation compared to the IACtHR's approach: ${ }^{55}$ the right to life of the Ogiek community has been understood as limited to the physical survival of the community, ${ }^{56}$ while there is no reference to the FPIC requirement prior access to natural resources. ${ }^{57}$ Nevertheless, it must be acknowledged that the Ogiek decision reveals also encouraging developments: ACtHPR appears sensible to the 'effet utile' doctrine in respect of the right to non-discrimination, ${ }^{58}$ and it repeatedly resorts to external sources - concretely employing the legal mandate given by Articles 60 and 61 of the African Charter for such purpose. ${ }^{59}$ However, these developments still appear to be insufficient to envisage - at least in the near future - the opening of the ACtHPR's jurisprudence to the most advanced doctrines developed by IACtHR allowing the Court to increase its overall mandate: primarily, the conventionality control doctrine. ${ }^{60}$ And this is not good, if we consider how the latter - although still triggering criticism $-{ }^{61}$ has proved to be crucial in the development

International Law 3.

55. African Commission on Human and People's Rights $v$ Republic of Kenya (Ogiek Decision), African Court on Human and Peoples' Rights (ACtHPR), Judgement, Application No. 006/2012, 26 May 2017; Killander, Gyan Nyarko, 'Recent developments: Human rights developments in the African Union (January 2017-September 2018)', 2018, 18 African Human Rights Law Journal, $p 751$.

56. African Commission on Human and People's Rights $v$ Republic of Kenya (Ogiek Decision), African Court on Human and Peoples' Rights (ACtHPR), Judgement, Application No. 006/2012, 26 May 2017, para [153]

57. African Commission on Human and People's Rights $v$ Republic of Kenya (Ogiek Decision), African Court on Human and Peoples' Rights (ACtHPR), Judgement, Application No. 006/2012, 26 May 2017, para [195-201-; IntLawGrrls, Ogiek: The African Court of Human and Peoples' Rights first decision on indigenous rights, by D. Townsend, 28 May 2017.

58. African Commission on Human and People's Rights $v$ Republic of Kenya (Ogiek Decision), African Court on Human and Peoples' Rights (ACtHPR), Judgement, Application No. 006/2012, 26 May 2017, para [136-146].

59. By way of illustration: African Commission on Human and People's Rights v Republic of Kenya (Ogiek Decision), African Court on Human and Peoples' Rights (ACtHPR), Judgement, Application No. 006/2012, 26 May 2017, paras [106], [125], [128], [131].

60. Huneeus, Rask Madsen, 'Between universalism and regional law and politics: a comparative history of the American, European, and African human rights systems', 2018, 16 International Journal of Constitutional Law 1, p 152-153.

61. Burgorgue-Larsen, 'Decompartmentalization: the Key Technique for Interpreting Regional Human Rights Treaties', 2018, 16 International Journal of Constitutional Law 1, p 198. of human rights standards in the Inter-American system, ${ }^{62}$ also through the institutionalization of the dialogue towards domestic Courts. ${ }^{63}$ As previously mentioned, a second crucial difference between IACtHR and ACtHPR consists in how they utilise their legal mandates on reparations in favour of the victims of human rights' violations. ${ }^{64}$ The Inter-American Court has not infrequently granted a broad range of remedies ${ }^{65}$ - both victimcentred and directed to the society as a whole 'that go far beyond financial compensation'66. A great number of its judgements could be taken as evidence of such expansionist approach. ${ }^{67}$ The decision Saramaka v Surinam encompasses - along with specific measures of compensation of material and immaterial damages - a comprehensive variety of additional positive obligations, inter alia measures of satisfaction and guarantees of non-repetition. Furthermore, it is worth mentioning that here IACtHR historically recognises the victim status - and the consequential entitlement to reparations - to the Saramaka community as a whole, rather than to its individual members. ${ }^{68}$ On this issue too, the

62. Bantekas and Oette, International Human Rights Law and Practice, Cambridge University Press, Second Edition, 2016, p 143; Ferrer Mac-Gregor, 'Conventionality Control: the New Doctrine of the Inter-American Court of Human Rights', 2015, 109 American Journal of International Law, p 95, 98-99; Engstrom, 'Reconceptualising the Impact of the Inter-American Human Rights System,' 2017, 2 Revista Direito and Praxis 8, p 1266.

63. Völkerrechtsblog, The Inter-American System has always been in crisis, and we always found a way out": an interview with Eduardo Ferrer Mac-Gregor Poisot, by L. Sanchez and R. Kunz, 17 October 2016.

64. Heyns, Padilla, Zwaak, 'A schematic comparison of Regional Human Rights Systems: an update', 2006, 3 International Journal on Human Rights 4, p 168.

65. Bantekas and Oette, International Human Rights Law and Practice, Cambridge University Press, Second Edition, 2016, $p$ 142.

66. Völkerrechtsblog, The Inter-American System has always been in crisis, and we always found a way out": an interview with Eduardo Ferrer Mac-Gregor Poisot, by L. Sanchez and R. Kunz, 17 October 2016.

67. Antkowiak, 'Remedial Approaches to Human Rights Violations: The Inter-American Court of Human Rights and Beyond', 2008, 46 Columbia Journal of Transnational Law 2, $p$ 353 (and following).

68. Saramaka People $v$ Suriname, Inter-American Court of Human Rights (IACtHR), Judgement (Merits, Reparations and Costs), Series C No. 172, 28 November 2007, para [189]; Lixinski, 'Treaty Interpretation by the Inter-American Court of Human Rights: Expansionism at the Service of the Unity of International Law, 2010, 21 The European Journal of International Law 3, p 599, 602-603; Brunner, 'The Rise of Peoples' Rights in the Americas: The Saramaka People Decision of the Inter-American Court of Human Rights', 2008, 7 Chinese Journal of International Law 3. 
African Court appears to be far more prudent. ${ }^{69}$ As a meaningful illustration of its approach, it is enough to consider the abovementioned Ogiek decision: the ACtHPR refrains from ordering any specific remedy or reparation to the victims. Conversely, the Court just orders Kenya 'to take all appropriate measures [...] to remedy all the violations established'.70

\section{CONCLUDING OBSERVATIONS}

To define in a nutshell the overall evaluation of the considered systems, it could be borrowed the picturesque metaphor 'from a cat into a lion' ideated by Professor Viljoen. ${ }^{71}$ The Inter-American system is already a roaring lion: fully grown and

69. Antkowiak, 'Remedial Approaches to Human Rights Violations: The Inter-American Court of Human Rights and Beyond', 2008, 46 Columbia Journal of Transnational Law 2, $p$ 359.

70. African Commission on Human and People's Rights $v$ Republic of Kenya (Ogiek Decision), African Court on Human and Peoples' Rights (ACtHPR), Judgement, Application No. 006/2012, 26 May 2017, para [227].

71. Viljoen, 'From a cat into a lion? An overview of the progress and challenges of the African human right system at the African Commission's 25-year mark', 2013, 17 Law, Democracy and Development. holding sharp claws to adequately protect and promote human rights. However, a lion is always in danger of becoming lazy and resting on more comfy doctrines - the margin of appreciation amongst all $-{ }^{72}$ especially when it starts to listen to some captivating bad advisers. ${ }^{73}$ On the contrary, the African system is still a growing cat: just in its early stages, often scared by jumping too high, and not yet boasting full autonomy and independence. Nevertheless - like all the cats - it is amazingly curious about the surrounding world and open-minded towards any external source. But most importantly, that metaphor reminds us a greater truth. Every lion has been a cat in its past, and every cat will be someday a lion: studying the historical development of each cat is the real key to understand the lion.

\section{BIBLIOGRAPHY}

- African Commission on Human and Peoples' Rights, Social and Economic Rights Action Center (SERAC) and Center for Economic and Social Rights (CESR) $v$ Nigeria, Communication No. 155/96, 27 May 2002.

- African Commission on Human and People's Rights $v$ Republic of Kenya (Ogiek Decision), African Court on Human and Peoples' Rights (ACtHPR), Judgement, Application No. 006/2012, 26 May 2017.

- Antkowiak, 'Remedial Approaches to Human Rights Violations: The Inter-American Court of Human Rights and Beyond', 2008, 46 Columbia Journal of Transnational Law.

- Bantekas and Oette, International Human Rights Law and Practice, Cambridge
University Press, Second Edition, 2016.

- B u r g o r g u e - L a r s e n, 'Decompartmentalization: the Key Technique for Interpreting Regional Human Rights Treaties', 2018, 16 International Journal of Constitutional Law 1.

- Canton, 'To Strengthen Human Rights, Change the OAS (Not the Commission)', 2013, 20 Human Rights Brief 2.

- Contesse, 'The Inter-American Court of Human Rights' Advisory Opinion on Gender Identity and Same-Sex Marriage', 2018, 22 American Society of International Law - Insights 9. Dulitzky, 'An Alternative Approach to the Conventionality Control Doctrine', 2015, 
109 American Journal of International Law.

- Engstrom, 'Reconceptualising the Impact of the Inter-American Human Rights System', 2017, 2 Revista Direito and Praxis 8.

- Goldman, 'History and Action: The InterAmerican Human Rights System and the Role of the Inter-American Commission on Human Rights', 2009, 31 Human Rights Quarterly 4.

- Gyan Nyarko, Oluborode Jegede, 'Recent developments: Human rights developments in the African Union during 2016', 2017, 17 African Human Rights Law Journal.

- Heyns, Padilla, Zwaak, 'A schematic comparison of Regional Human Rights Systems: an update', 2006, 3 International Journal on Human Rights 4.

- Huneeus, Rask Madsen, 'Between universalism and regional law and politics: a comparative history of the American, European, and African human rights systems', 2018, 16 International Journal of Constitutional Law 1.

- Inter-American Commission on Human Rights (IACHR), Severe Financial Crisis of the IACHR Leads to Suspension of Hearings and Imminent Layoff of Nearly Half its Staff, Press Release, 23 May 2016.

- IntLawGrrls, Ogiek: The African Court of Human and Peoples' Rights first decision on indigenous rights, by D. Townsend, 28 May 2017.

- Killander, Gyan Nyarko, 'Recent developments: Human rights developments in the African Union (January 2017-September 2018)', 2018, 18 African
Human Rights Law Journal, p 742, 757.

- Lixinski, "Treaty Interpretation by the Inter-American Court of Human Rights: Expansionism at the Service of the Unity of International Law', 2010, 21 The European Journal of International Law 3.

- Pinto, 'The Role of the Inter-American Commission and Court of Human Rights in the Protection of Human Rights: Achievements and Contemporary Challenges', 2013, 20 Human Rights Brief 2.

- Saramaka Peoplev Suriname, Inter-American Court of Human Rights (IACtHR), Judgement (Merits, Reparations and Costs), Series C No. 172, 28 November 2007.

- University of Pretoria, Centre for Human Rights (Faculty of Law), Centre for Human Rights Calls for Autonomy and Independence of the African Commission to Be Reaffirmed; and for Action on Cameroon and Eritrea, 28 April 2018.

- Völkerrechtsblog, The Inter-American System has always been in crisis, and we always found a way out": an interview with Eduardo Ferrer Mac-Gregor Poisot, by L. Sanchez and R. Kunz, 17 October 2016.

- Viljoen, 'From a cat into a lion? An overview of the progress and challenges of the African human right system at the African Commission's 25-year mark', 2013, 17 Law, Democracy and Development.

- Gyan Nyarko, Oluborode Jegede, 'Recent developments: Human rights developments in the African Union during 2016', 2017, 17 African Human Rights Law Journal, p 304, 308. 